\title{
RISK FACTORS OF CEREBRAL PALSY WITH SYMPTOMATIC EPILEPSY
}

\section{*Sadikova G.K., Khamidova S.M., Agzamhadjayeva B.U.}

Tashkent Pediatric Medical Institute, Department of Neurology, Child neurology and Medical Genetics, Tashkent, Uzbekistan

Palmer F.B., Hoon A.H. (1993) wrote that cerebral palsy (CP) - a violation of the motor functions of the cortex and lesion of the immature brain, including psychomotor retardation in combination with neurological disorders: cognitive, behavioral, sensory, orthopedic problems. The frequency of $\mathrm{CP}$ in the population is 2.5 per 1,000 live births. In recent years, the frequency of this disabling condition is constantly growing. Many studies show a significant frequency difference of 0.76 to 5.8 per 1,000 children, which varies by region and year (Badalyan LO et al, 1988, Suleimenova RA, 2001, Shipitsyna LM, Mamaychuk II, 2001).

$\mathrm{CP}$ is one of the most actual problems of pediatric neurology. Given the life course of the disease, it is of paramount as health and socio - economic importance. Permanent rehabilitation activities carried out throughout the life of the patient, lay an enormous burden not only on every single family, but also for the state as a whole.

The prevalence of CP is 5-8 per 1000 population, seizures $-2-3 \%$ in the pediatric population [ED Belousov, 2003; Tsybulsky VB, 2005]. Opinions about the frequency of seizures in children with $\mathrm{CP}$ in the literature are quite contradictory - from 11.5 to $90 \%$ [VA Klimenko, 1993; Solovykh H.H., 1998; Belousov V., 2009;] Problem of interrelation of these diseases is extremely relevant in pediatric neurology. Its importance is determined by: a variety of clinical paroxysms; resistance to the attacks of anticonvulsant therapy in $25-30 \%$ of cases [Pcllock JM, 2000]; aggravation under their influence the severity of existing neuropsychiatric disorders complication rehabilitation measures [Hadjipanayis A. et al., 1997; Bruck I. et al., 2001]. Issues of medical rehabilitation of children with $\mathrm{CP}$ have repeatedly been subjected to domestic research scientists KA Semenova (1968), SA Bortfelda (1971), LO Badalyan (1984), TG Shamarina (1984), EG Sologubova (1992), etc. However, these works focus mainly concerns problems of etiology and pathogenesis of $\mathrm{CP}$, as well as the possibilities of its non-drug treatments.

In the modern period, it is proved that the leading role played by prenatal factors. According to most scientists (Badalyan LO et al, 1988, Semenov, KA, 1999, Volp II, 1974, 1995, Tom Thumb, AB 1998, AB Thumb, Shabalov, 2000) prenatal factors account for more than $90 \%$. Often in patients with CP there are various types of symptomatic epilepsy, which complicates the course and prognosis of the disease. In this regard, the aim of our study was: to explore the risk factors of cerebral palsy with symptomatic epilepsy.

Materials and methods: in the retrospective and prospective studies we have observed 49 children with various forms of CP (26 boys and 23 girls) with different forms of seizures: generalized in 36 children, absence in 3 children, tonic in 6 patients and clonic character in 4 children. The age of patients at the time of the analysis of clinical data ranged from 7 days to 7 years.

In accordance with the selected prenatal factors we identified two main groups, which gave a high implementation rate of $\mathrm{CP}$ :

1 - group - children with low body weight, the rapid development of periventricular leukomalacia and periventricular cyst formation, low Apgar score, a long period of jaundice requiring resuscitation measures immediately after birth and the syndrome of oppression.

2 - group - children with intrauterine infection and chronic hypoxia, the formation of rough morphological hearth, seizures in the neonatal period.

Results. Given our data, risk factors for CP were:

1) the highest percentage amounted to prenatal factors $(77.6 \%)$, among which is the state of health of the mother, implying that migrated intrauterine infection, a significant part of which belongs to

* e-mail: madjidova1@yandex.ru 
the herpes infection - 28.4\%. Significant number of women $(65 \%)$ had anemia of varying severity, including endocrine disorders, and autoimmune dominated endogenous goiter.

2) The second place of the risk of disease was prematurity: 22 patients were born preterm with a term of less than 37 weeks of $22.4 \%$, and weighing less than $1500 \mathrm{~g} \mathrm{13.64 \%} \%$. Our findings are consistent with other studies conducted in preterm infants. Of these, $18.9 \%$ of children with CP were of twins, which also ended with prematurity and the risk of $\mathrm{CP}$.

Etiological factor impact on the fetus in the prenatal period, in any case ended with fetal hypoxia, the formation of morphological defects, including congenital threshold of the central nervous system constituted $33.2 \%$.

\section{REFERENCES}

1. Palmer F.B., Hoon A.H. Cerebral palsy//Behavioral and developmental pediatrics. Eds. S. Parker, B. Zucherman. Boston: Little, Brown and Co. -1995.-P.88-94.

2. Семенова К.А. Детские церебральные параличи//Неврология детского возраста. -Минск: Вышэйшая школа.- 1990.-Т2-с.165-206.

3. Бадалян Л.О., Журба Л.Т., Тимонина О.В. Детские церебральные параличи. - Киев: Здоровья, -1988.-327с. 4. Nelson K.B., Ellenberg J.H. Apgar scores as Predictors of chronicneurology: Pediatrics. -1981.-Vol.68,№1,-P.36-44 5. Козлова С.И., Семанова Е., Демикова Н.С., Блинникова О.Б.Наследственные синдромы и медико-генетическое консультирование/Справочник. -Л.-1987.

6. Скворцов И.А. Детство нервной системы.-М.-1995.c.63-64

7. Качесов В.А. ДЦП.-С.Петербург.-ЭЛБИ-СПб.2005.-111c.
Thus, the implementation of these factors indicate CP inappropriate formation of ontogenesis brain at different stages of development, leading to the formation of the morphological defect, among which are formed by leading central nervous system malformations (Barrels NP, 1971, 1978, Kennedy MR, 1974, Badalyan LO, 1981, IA Skvortsov, 1991, Feeman JM 1985).

Conclusion. Thus, our studies showed that the risk of cerebral palsy is a prenatal factor and prematurity. Therefore, to control and prevent the risk of cerebral palsy with convulsive syndrome requires timely, regular, strict observation of pregnant women with pathological premorbid and early hospitalization and treatment of pregnant at the risk of giving birth prematurely.

8. Симбирцев А.С.//Цитокины и воспаления.-2002.№1.-c.9-16

9. Swanson M.W., Bennet F.C. Shy K.K.e.a. Identification of neurodevelopmentalabnormality at four and eight months by the movementassessment of infants. Developmen. Medicine and Child Neurology,1992, Vol.34, P.321-337.

10. Wellesley D.J., Hockey K.A., Montgomery Ph.D. Prevalence ofintellectual handicap in Western Australiai a community stady. The Med.J. of Australia, 1992, Vol.156(2), P.94-94.

11. Акимов В.О. Синдром Фара и детский церебральный паралич- последствия тяжелейшей родовой гипоксии у ребенка. Архивпатологии, 1991, 53, 5-7.

12. Little W.J. On the influence of abnormal difficaltlabours, prematurebirth and asphyxia neonatorum on the mental and physical conditionof the child. Trans. Obstet., $1862,3,293-344$.

\title{
РЕЗЮМЕ
}

\section{ФАКТОРЫ РИСКА ДЕТСКОГО ЦЕРЕБРАЛЬНОГО ПАРАЛИЧА СО СИМПТОМАТИЧЕСКОЙ ЭПИЛЕПСИЕЙ}

\author{
Садикова Г.К., Хамидова С.М., Агзамходжаева Б.У. \\ Кафедра неврологии, детской неврологии Ташкентского Педиатрического Медицинского Института, \\ Ташкент, Узбекистан
}

Детский церебральный паралич (ДЦП) - одна из наиболее актуальных проблем детской неврологии. В данной статье в процессе ретроспективного и проспективного исследования проведен анализ у 49 детей с различными формами ДЦП (26 мальчиков и 23 девочек) у которых заболевание протекает с различными формами судорог: генерализованный у 36 детей, абсанс у 3 детей, тонический у 6 и клонический характер у 4 детей. Возраст пациентов на момент анализа клинических данных варьировал от 7 дней до 7 лет. С учетом наших данных, факторами риска ДЦП явились:

1) Наибольший процент составили пренатальные факторы $(77,6 \%)$, среди которых выделяются, 
состояние здоровья матери, подразумевая под этим перенесенные внутриутробные инфекции, значительная роль среди которых принадлежит герпетической инфекции - 28,4\%. Значительное количество женщин (65\%) страдали анемией различной степени тяжести, среди эндокринных расстройств доминировали эндогенный и аутоиммунный зоб. 2) Второе место среди рисков развитие болезни явилось недоношенность: 22 больных родились недоношенными, со сроком менее 37 недель $22,4 \%$, а с весом менее 1500 г 13,64\%. Таким образом, проведенные нами исследования показало, что риском развития ДЦП является пренатальный фактор и недоношенность.

Ключевые слова: ДЦП с эпилепсией, осложнения у недоношенных детей.

\title{
XÜLASכ
}

\section{SIMPTOMTIK EPILEPSIYYLI UŞAQ SEREBRAL İFLİCININ RİSK AMILLORİ}

\author{
Sadikova Q.K., Xamidova S.M., Aqzamxocayeva B.U. \\ Daşkənd pediatrik tibb institutunun nevrologiya, uşaq nevrologiyası kafedrası, Daşkənd, Özbəkistan
}

Uşaq serebral iflici (USİ) - uşaq nevrologiyasının ən aktual problemlərindən biridir. Təqdim edilmiş məqalədə retrospektiv və prospektiv tədqiqatlar nəticəsində 49 müxtəlif formalı USİ-dən əziyyət çəkən uşaqlar müayinə edilmişdir (26 oğlan, 23 qız) ki, bunların da hamısında müxtəlif formalı qicolma tutmaları olmuşdur generalizə olunmuş 36, absans 3, tonik 6, klonik 4 xəstə. Klinik məlumatların toplanması momentində xəstələrin yaşı 7 gün-7 yaş arası idi. Bizim məlumatlara əsaslanaraq USİ-nin risk amilləri belə olmuşdur:

1) Aralarında əhəmiyyətli rolu herpetik infeksiyalar $(28,4 \%)$ oynayan, keçirilmiş bətndaxili infeksiyaları nəzərdə tutan ananın sağlamlığının vəziyyəti ayırd edilən prenatal faktorlar (77,6\%) saha çox faiz təşkil etmişdir. Qadınların əhəmiyyətli dərəcəsi (65\%) müxtəlif ağırlıqlı anmeiyadan əziyyət çəkmiş̧ir, endokrin pozulmalardan endogen və autoimmun zob üstünlük təşkil etmişdir.

2) USİ-nin inkişaf riskləri arasında vaxtından əvvəl doğulma ikinci yeri tutmuşdur: xəstələrdən 22 nəfər vaxtından əvvəl doğulmuşdur, 37 həftədən az müddətdə 22,4\%, 1500 q çəkidən az olanlar 13,64\% təşkil etmişdir. Beləliklə bizim tədqiqatın nəticələri göstərdi ki, USİ-nin inkişaf riskinə prenatal faktor və vaxtından əvvəl doğulma aiddir.

Açar sözlər: epilepsiya ilə USİ, vaxtından əvvəl doğulan uşaqlarda ağırlaşmalar.

Redaksiyaya daxil olub: 3.05 .2014

Çapa tövsiyə olunub: 01.06.2014

Rayçi: t.e.d., prof. R.K.Şiraliyeva 